\title{
Field trials of thin-lift deposition of amended mature fine tailings at the Muskeg River Mine in Northern Alberta
}

\author{
J.G. Matthews Shell Canada, Canada \\ N. Dhadli Shell Canada, Canada \\ P. House Shell Canada, Canada \\ P. Simms Carleton University, Canada
}

\begin{abstract}
In response to regulatory directives that tailings achieve a given shear strength within a certain time subsequent to deposition, oils sands operations in Northern Alberta are aggressively investigating several new deposition techniques. Shell has plans to deploy a number of tailings management technologies that will deliver on corporate sustainability objectives and regulatory requirements. Technologies currently planned for deployment are identified in Shell regulatory submissions and include thickened tailings, composite tailings, non-segregating tailings, centrifugation of fine tailings, and atmospheric fines drying. This paper will provide a brief introduction to atmospheric fines drying (AFD) process. The AFD process entails amendment of fluid fine tailings (FFT) with a flocculating polymer such that rheology and depositional characteristics are modified, water release is enhanced upon deposition and the deposits are managed to enhance the rate of dewatering such that the fluid tailings have geotechnical strength properties. Shell Canada commenced large scale AFD trials in August 2010. The field program involves nine separate cells, each 30,000-40,000 $\mathrm{m}^{2}$ in plan, approximately $300 \mathrm{~m}$ long, radiating from a central staging area. Each cell is graded with a designated slope, ranging from 0.5-1.5\%. The cells are separated by berms. A range in lift sizes $(0.1-0.5 \mathrm{~m})$ are to be investigated as a controlling parameter for AFD performance. The paper documents some preliminary results from the operation with respect to i) achieving a given level of polymer mixing and controlling the rheology of the tailings emerging the pipe, ii) controlling the geometry of the tailings during deposition, and iii) the degree of densification and shear strength gain achieved by settling, consolidation, and desiccation.
\end{abstract}

\section{Introduction}

Tailings generated from surface excavation operations in oil sands contain a higher percentage of fines and clay minerals compared to other kinds of mining. This is due to interlaying of seams of clay and shale with the sand layers containing bitumen. Whole tailings originating from the extraction process typically have solids concentrations ranging from $40-60 \%$ and fines content $(<44 \mu \mathrm{m})$ of $15-30 \%$. Conventionally deposited in dammed impoundments, the coarse fraction beaches out, leaving a suspension of fine tailings (fines content $>90 \%$ ) with a solids concentration less than $8 \%$. After 2-3 years, the solids concentration at depth in the pond increases through settling to about 30\%, past which point any significant increases in solids concentration due to consolidation is very slow. These fine tailings are called mature fine tailings (MFT). The consequences of the slow consolidation of MFT are the necessary construction and maintenance of large footprints of dammed impoundments, water costs associated with irrecoverable water losses to the tailings, risk of seepage or dam breach and the requirement to minimise interaction of the pond with biota.

Shell sees the amendment and distribution of flocculated MFT as a natural extension of tailings thickening technologies that have been employed at Shell Albian Sands operations since start-up. Shell recognised significant opportunities to learn and adapt thin-layer deposition of the kind already used in specific operation in hard rock mining and red mud tailings disposal operations for implementation in an oil sands context. Consequently, several oil sands operators have embarked upon field trials of thin-layer deposition, in conjunction with the injection of aggregating amendments (flocculants) at some point close to deposition 
points. The goal of these operations is to maximise dewatering and strength gain in the tailings, through a combination of settling accelerated by the additive, desiccation and consolidation.

Shell Canada has recently started their field trial at the Muskeg River Mine near Fort McMurray (Figure 1) in Northern Alberta. The field trial involves the following:

- Harvesting high-density (30-40 wt $\%$ solids) MFT from the tailings storage facility.

- Inline mixing of the MFT with a flocculant.

- Depositing the MFT into a deposition cell such that a gentle sloped stack is formed and an immediate initial water release is observed due to the addition of the flocculant. Tailings deposition is cycled between nine different cells as shown in Figures 2 and 3.

- Collection and return of release water to the tailings storage facility.

- Atmospheric evaporation and under drainage of the deposit to a point where it is deemed ready for placement of a subsequent layer (initial target of an undrained shear strength of $5 \mathrm{kPa}$ as determined by in situ vane testing).

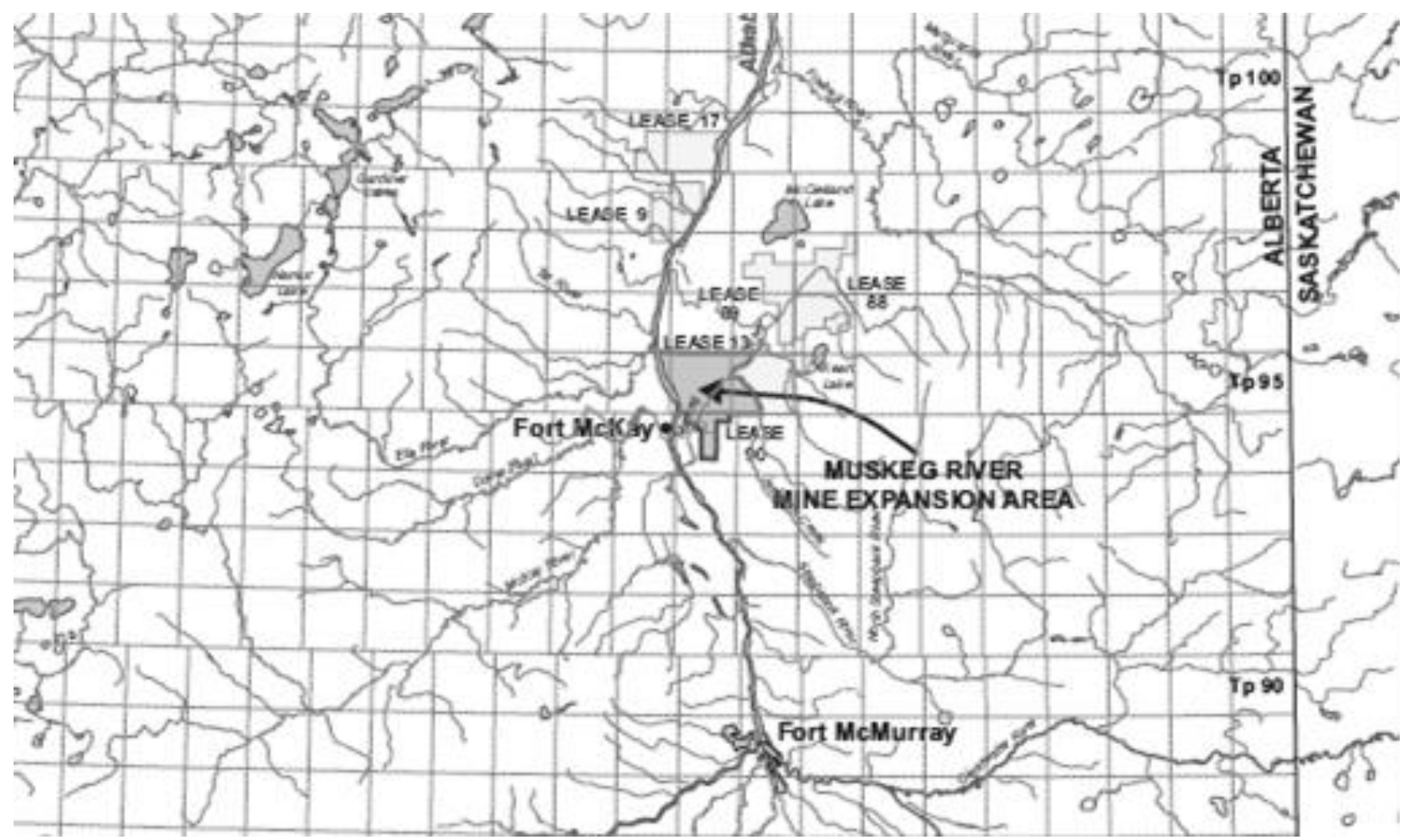

Figure 1 Location of the Muskeg River Mine, Alberta, Canada 


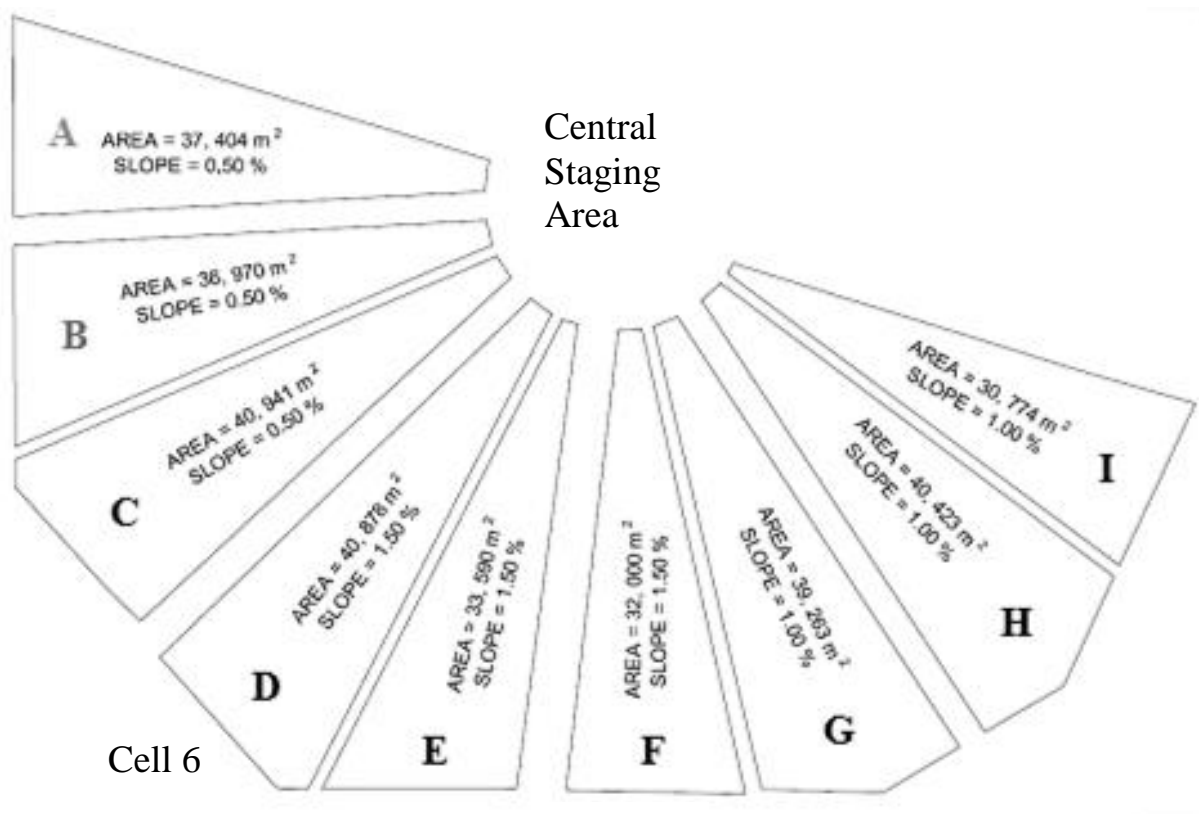

Cell 4

Figure 2 Deposition cell layout with percentage slopes for each cell

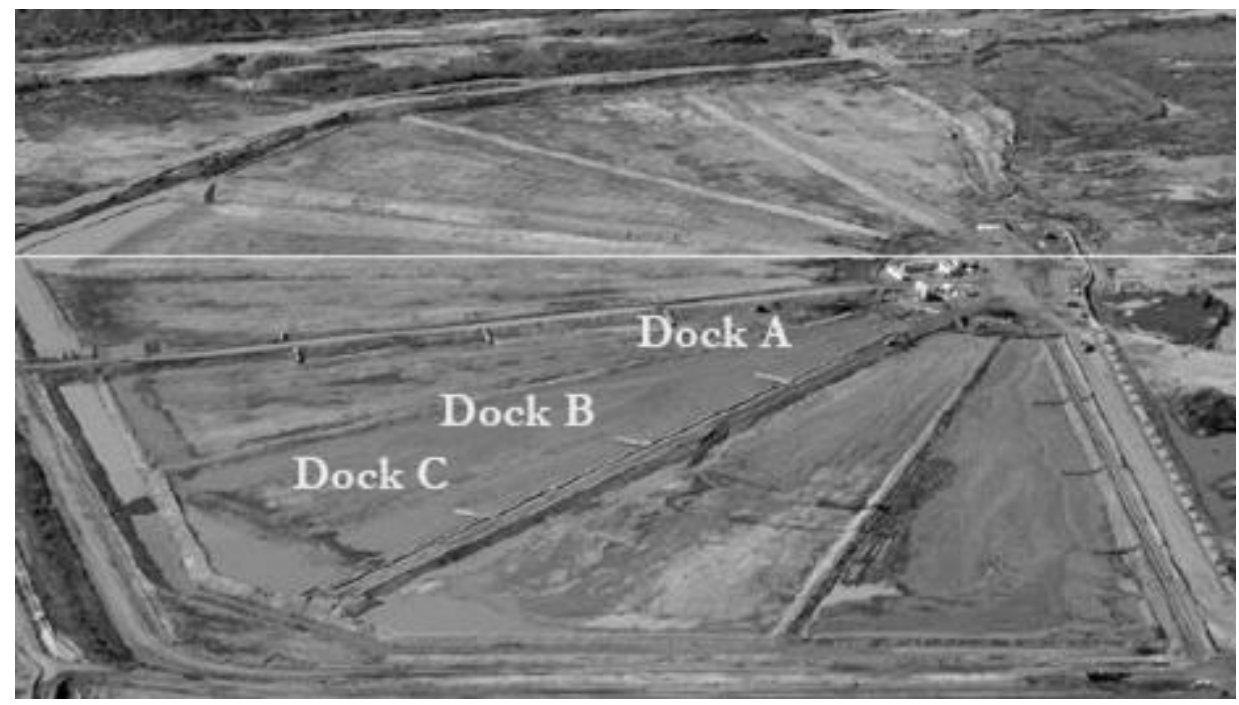

Figure 3 Deposition cells and location of instrument clusters (docks)

The field program comprises nine separate cells, each $30,000-40,000 \mathrm{~m}^{2}$ in plan, approximately $300 \mathrm{~m}$ long, radiating from a central staging area. Each cell is graded with a designated slope, ranging from $0.5-1.5 \%$ (Figure 2). The underlying soil is local fill that has a hydraulic conductivity of $\sim 2 \times 10^{-6} \mathrm{~m} / \mathrm{s}$, as determined by Guelph Permeameter tests. The goals of the field trial are to assess the amount and quality of initial water release occurring post-deposition, as well as to determine the time required to achieve a deposit shear strength of $5 \mathrm{kPa}$ or greater using thin-lift deposition, for a given set of climatic conditions and lift thickness. As the reuse of water is a crucial factor in oil sands operations, from both an economic and environmental perspective, release water with very little solids is highly desirable. The value of $5 \mathrm{kPa}$ undrained shear strength is a performance criterion mandated by the provincial regulator in Alberta (ERCB Directive 074) that applies to the fine tailings fraction $(<44 \mu \mathrm{m})$. Tailings must develop a shear strength of $5 \mathrm{kPa}$ within one year after deposition. 


\section{$2 \quad$ Materials and methods}

MFT was pumped from the nearby tailings storage facility. The initial solids concentration of the MFT ranged from $30-35 \%$ solids. The MFT has a specific gravity of 2.55 , liquid limit of $70 \%$ and a PI of $37 \%$. The $\mathrm{pH}$ of the pore-water was $8-9$.

The MFT was injected in-line with a polymer, less than a metre away from the deposition point. This was done to induce enhanced settling as the tailings are being deposited, without incurring the problems faced by pumping a thicker material. It is well known within the oil sands industry that the performance of the polymer is sensitive to the degree of mixing. Over-mixing tends to break down flocs, which defeats the purpose of adding the polymer. Therefore alternative polymer injection and mixing designs were trialled; including using a venturi, jet injection prior to static mixer, jet injection within a static mixer, and no mechanical mixing. Additionally, polymer dose as well as flow regimes (laminar versus turbulent) were varied to investigate mixing control. The initial phase of deposition was restricted to Cells $\mathrm{A}$ and $\mathrm{B}$, for optimisation of in-line mixing, while the remaining cells were intended to study influence of initial slope on lift deposition geometry and dewatering enhancement by drainage. The average polymer dose was 1 part polymer to 1,000 parts MFT solids by mass.

Samples were obtained from amended MFT emerging from the pipe at the deposition points and characterised using a slump (Pashias et al., 1996) and capillary suction time (CST) tests (Baskerville and Gale, 1968).

The tailings were pumped into a spill box (Figure 4) at the head of each cell, which they naturally overflow. The use of the spill box was to dissipate kinetic energy associated with the flow, to allow for better control and understanding of flow down the beach. Tailings were deposited at a variable rate from $650-1,000 \mathrm{~m}^{3} / \mathrm{hr}$.

The deposited tailings in each cell were monitored using instrument clusters placed at roughly equal spacing down the cell, placed approximately $5 \mathrm{~m}$ from the wall of the cell (Figure 3). Instrument clusters consisted of tensiometers (Model SW-031 from Soil Measurement Systems), volumetric water content sensors (Model CS645 from Campbell Scientific) and vibrating-wire piezometers (VW2100 from RST instruments). The tensiometers and volumetric water content sensors were installed at approximately $0.1 \mathrm{~m}$ intervals in the deposited tailings, while the piezometers were installed at intervals of about $0.3 \mathrm{~m}$. Where possible, samples of tailings were obtained for analysis of solids concentration. Shear strength was periodically tested using a field vane.

The evolution of tailings geometry during deposition was monitored by staff gauges at the docks. The geometry was also recorded periodically using a tripod based LIDAR technique.

Local climate conditions, including rainfall, net radiation, wind speed, relative humidity and temperature were monitored using an onsite weather station. Release water was collected at sumps at the base of each cell. This water was analysed for water chemistry and solids concentration.

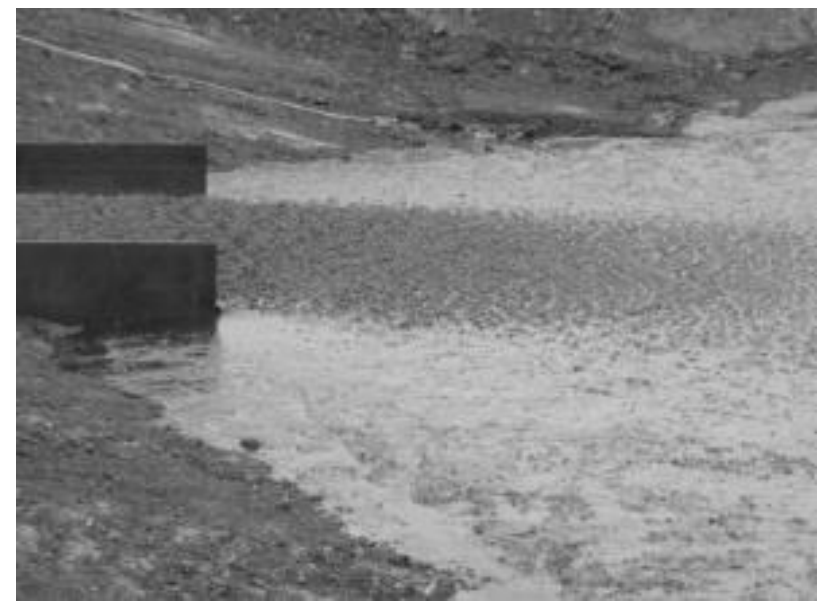

Figure 4 Amended MFT pouring out of spill box 


\section{$3 \quad$ Results}

A preliminary round of deposition trials were conducted in September - October 2010. Although much of the data is still undergoing processing and analysis, it is of interest to present some preliminary results.

While an optimal mixing approach (using a 96 inch static mixer) was identified, considerable variation in slump was still observed in the deposition trials. Yield stresses determined from slump tests using the method of Pashias et al. (1996) ranged from 35-370 Pa, with an average of $210 \mathrm{~Pa}$. This variation is correlated with variability in the feed MFT, in terms of clay content. Coincident with this variability in slump, a significant variability in the behaviour of overland flow was noted during deposition. During some trials, the tailings would quickly build up near the deposition point (Figure 5), and occasionally overflow the cell walls, whereas in other trials, the tailings would flow in a tight channel a considerable distance down the cell before spreading out. Future trials will examine alternate deposition schemes, potentially with multiple or moving deposition points, to better control lift geometry. Additionally, in-line monitoring of the MFT feed for clay content is also being contemplated.

Figure 5 also shows the release of water that begins to occur immediately after deposition starts. Release water from the tailings collected at the base of the cells showed solids concentrations generally less than $5,000 \mathrm{ppm}$, with a pH between 7 and 8.5.

Monitoring data from one of the cells (Cell 6) is shown in Figures 6 through 10, from deposition to when the tailings begin to freeze (September 18 - October 20). During this period, the average daily evaporation, as calculated using the Penman-Monteith equation and employing the climate data from the onsite weather station, was $0.65 \mathrm{~mm} /$ day. Cumulative rainfall in the same period was $48 \mathrm{~mm}$. The average temperature and relative humidity were $10^{\circ} \mathrm{C}$ and $70 \%$ respectively.

A clear trend with depth in terms of solid concentration, vane shear strength and rate of pore-water pressure (PWP) dissipation is shown in Cell 6, and is consistent across all the cells. Within a day after deposition, the bottom tailings already show the highest solids concentration (54\% compared to $43 \%$ at the top, Figure 7). In this cell, solids concentration increased to $59 \%$ at the bottom by October 3 , and had achieved a peak shear strength in excess of $3 \mathrm{kPa}$ (Figure 10).

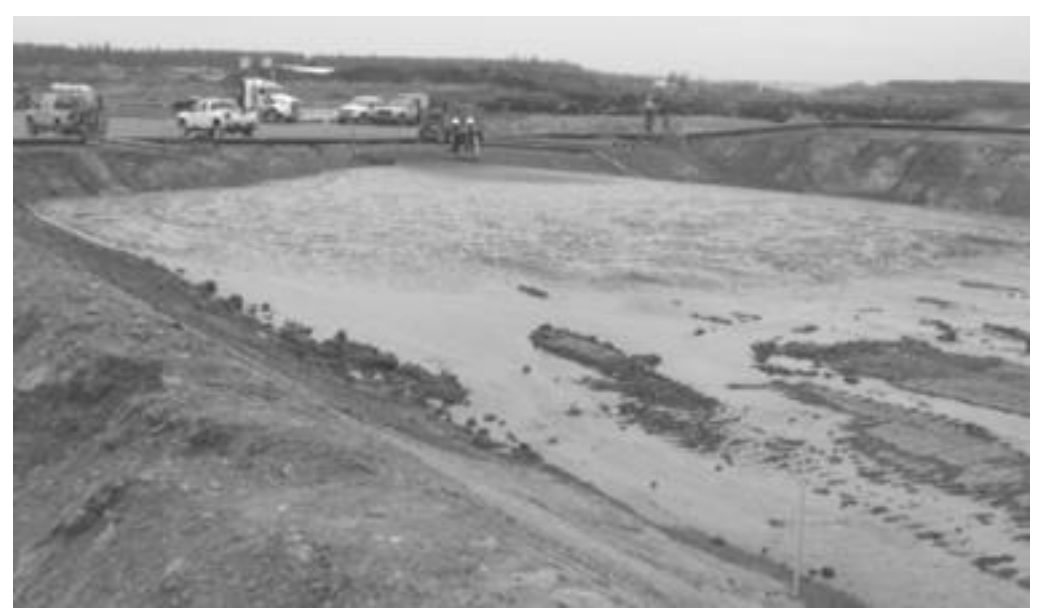

Figure 5 Early deposition in a cell, looking towards central staging area 


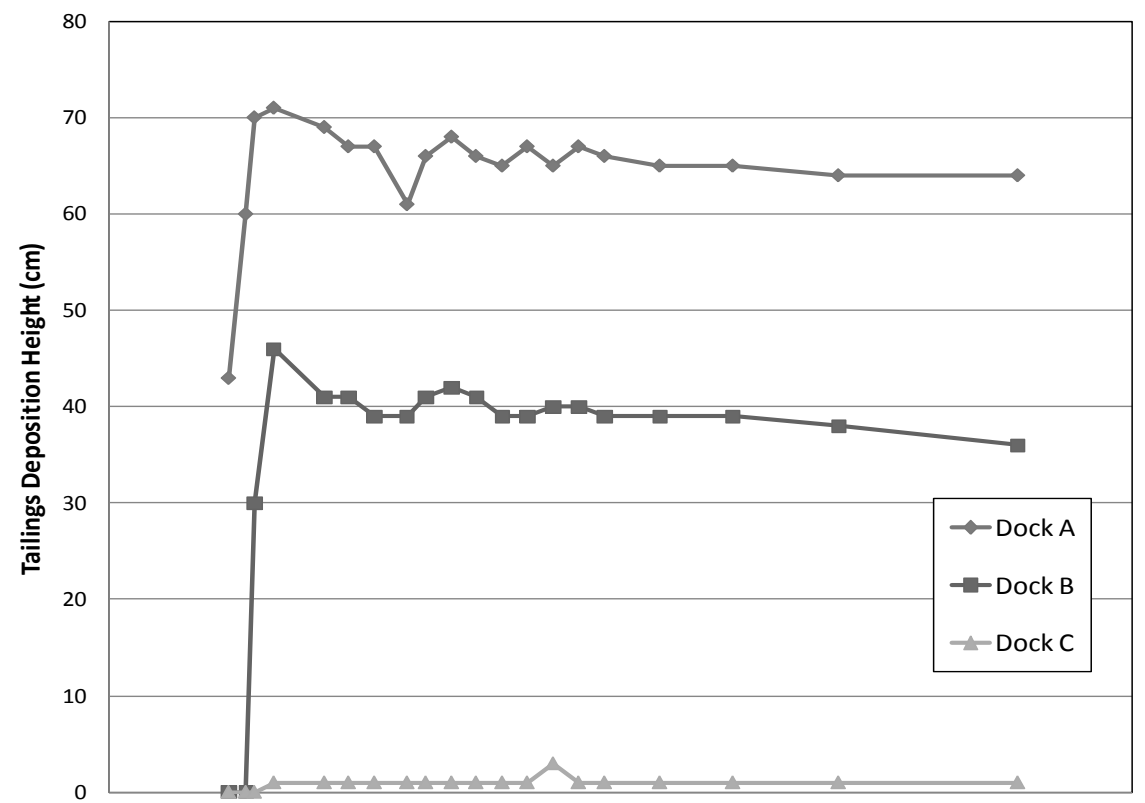

14/09/2010 19/09/2010 24/09/2010 29/09/2010 04/10/2010 09/10/2010 14/10/2010 19/10/2010 24/10/2010

Date

\section{Figure 6 Deposition profile in Cell 6}

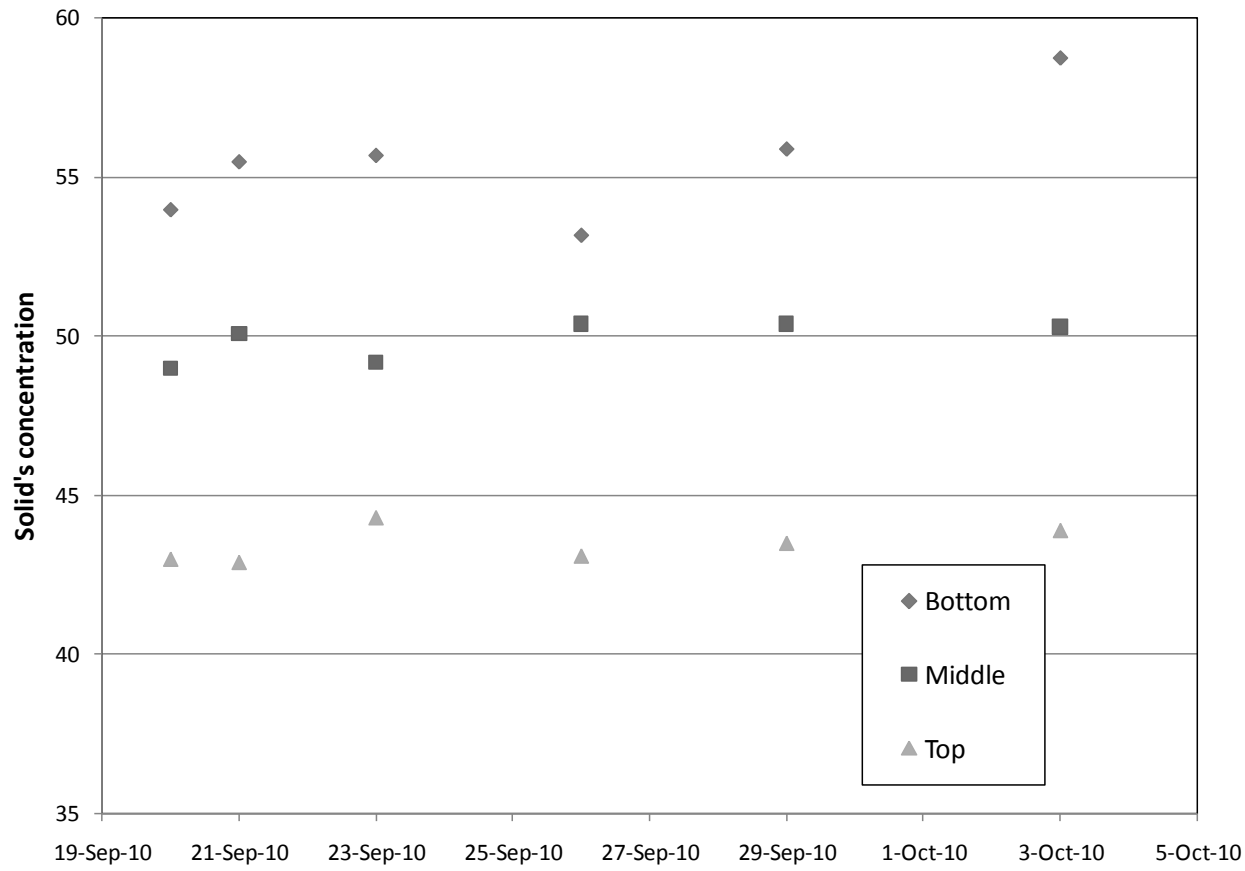

Figure 7 Solids concentration in Cell 6 


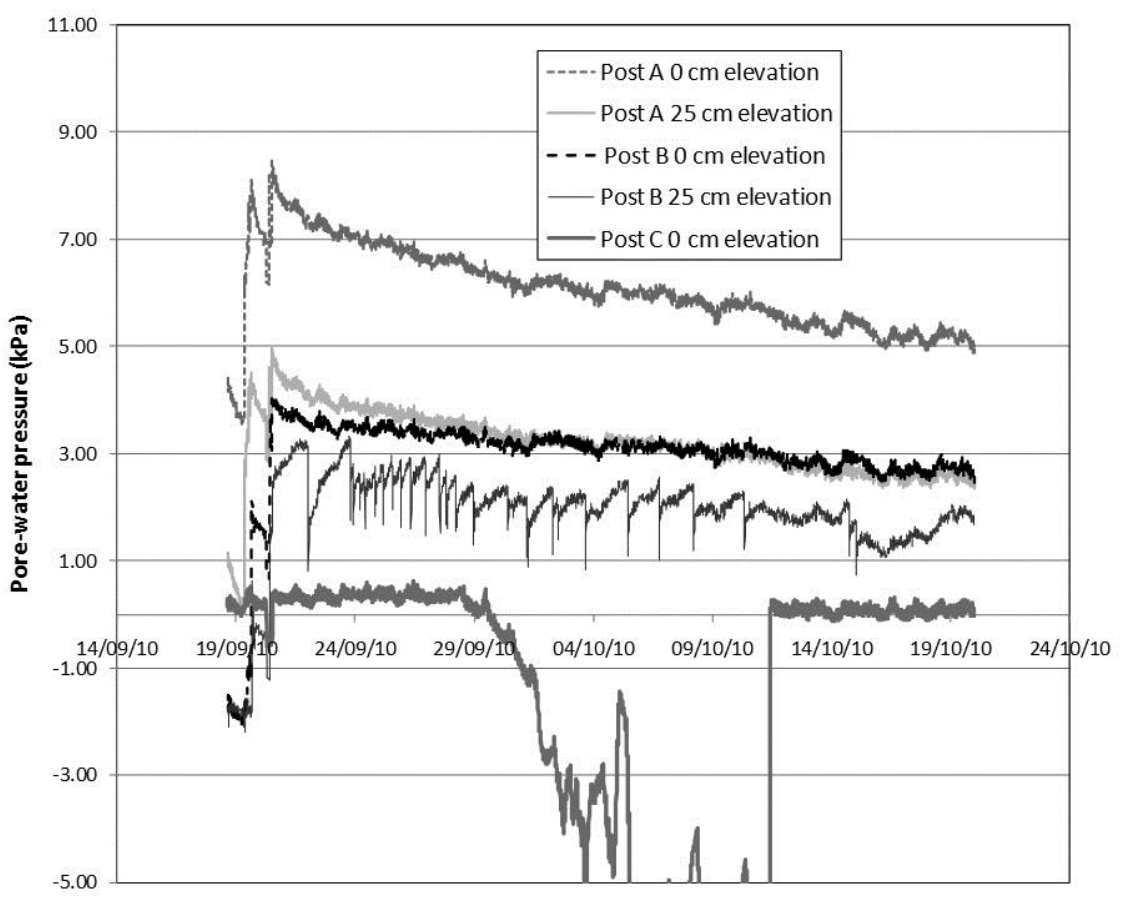

Figure 8 Pore-water pressures in Cell 6

The PWP data in Figures 8 and 9, along with the variation in solids concentration with depth (Figure 7), suggest a consolidation mechanism with bottom drainage as the primary mechanism for densification and PWP dissipation in this cell. Atmospheric forcing, before freezing, is only reflected in piezometers located very close to the surface, such as for Post C (only buried by $2-3 \mathrm{~cm}$ of tailings). This is not unexpected, due to the relatively wet conditions, and low evaporation rates during dry days. For a $30 \mathrm{~cm}$ lift, assuming most of the rain water runs off, evaporation would improve a $45 \%$ solids deposit to $47 \%$ solids, and a 55\% solids deposit to $58 \%$ solids. For a $10 \mathrm{~cm}$ lift, the increase would be to $53 \%$ and $64 \%$ solids, respectively. Looking at the PWP in another cell under $10 \mathrm{~cm}$ thickness of tailings (Figure 11), one can see some evidence of atmospheric forcing before freezing, in the negative curvature of the PWP plot between October 1 and 20. When the top surface of the tailings does starts to freeze (past October 20), significant further PWP dissipation does occur for this same thickness, even though the tailings do not freeze to the bottom until November 10. Therefore, consolidation induced by cryo-suctions may be a mechanism of interest in future trials.

The vane strengths for this cell (Figure 12), while they initially follow the same positive trend with increasing depth as in Cell 6, show some pick-up in the strengths at the top in October, possibly due to atmospheric forcing by evaporation or frost.

An example of the best performance, for a $30 \mathrm{~cm}$ depth of tailings, in terms of bearing capacity, is shown in Figure 13. The peak vane strength at this point was over $5 \mathrm{kPa}$. 


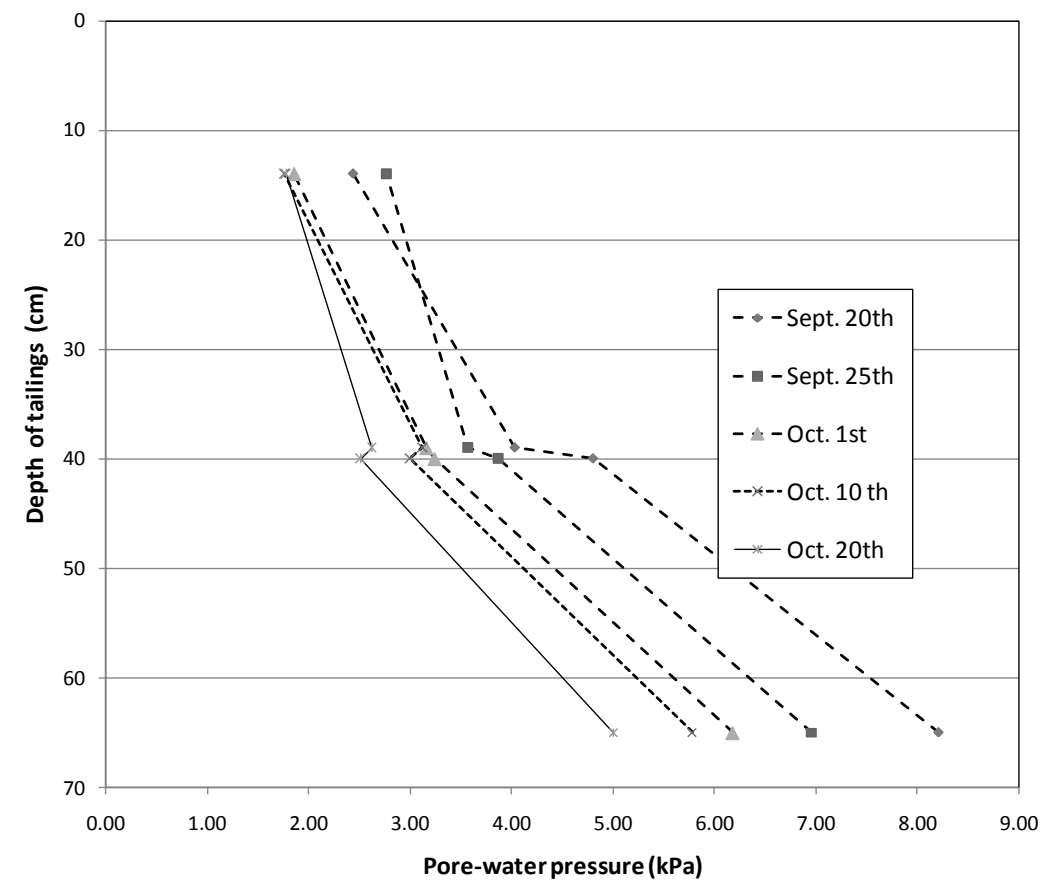

Figure 9 Depth profile of PWP in Cell 6, composite of docks A $(65 \mathrm{~cm}$ and $40 \mathrm{~cm})$ and $B(39 \mathrm{~cm}$ and $14 \mathrm{~cm})$

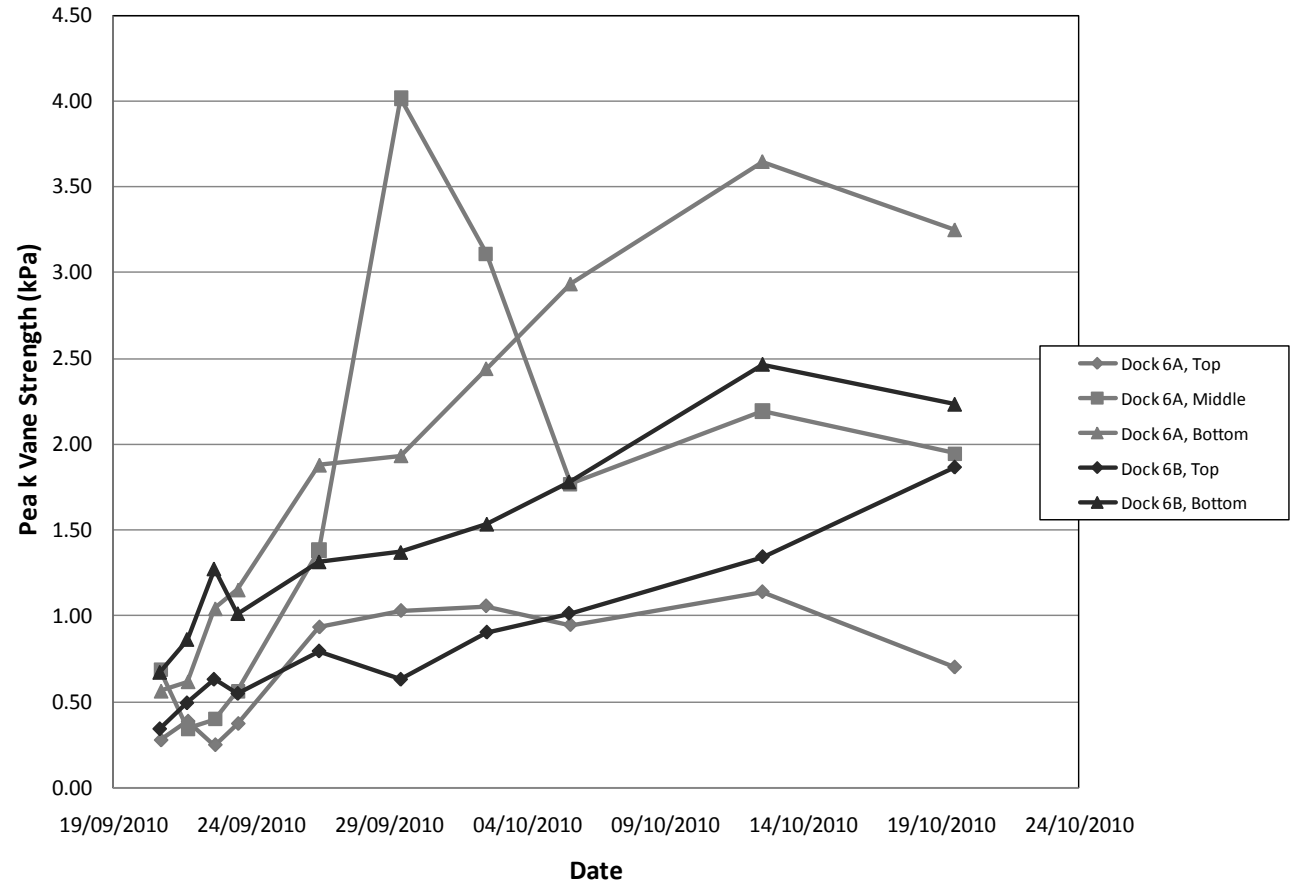

Figure 10 Peak vane strength in Cell 6 


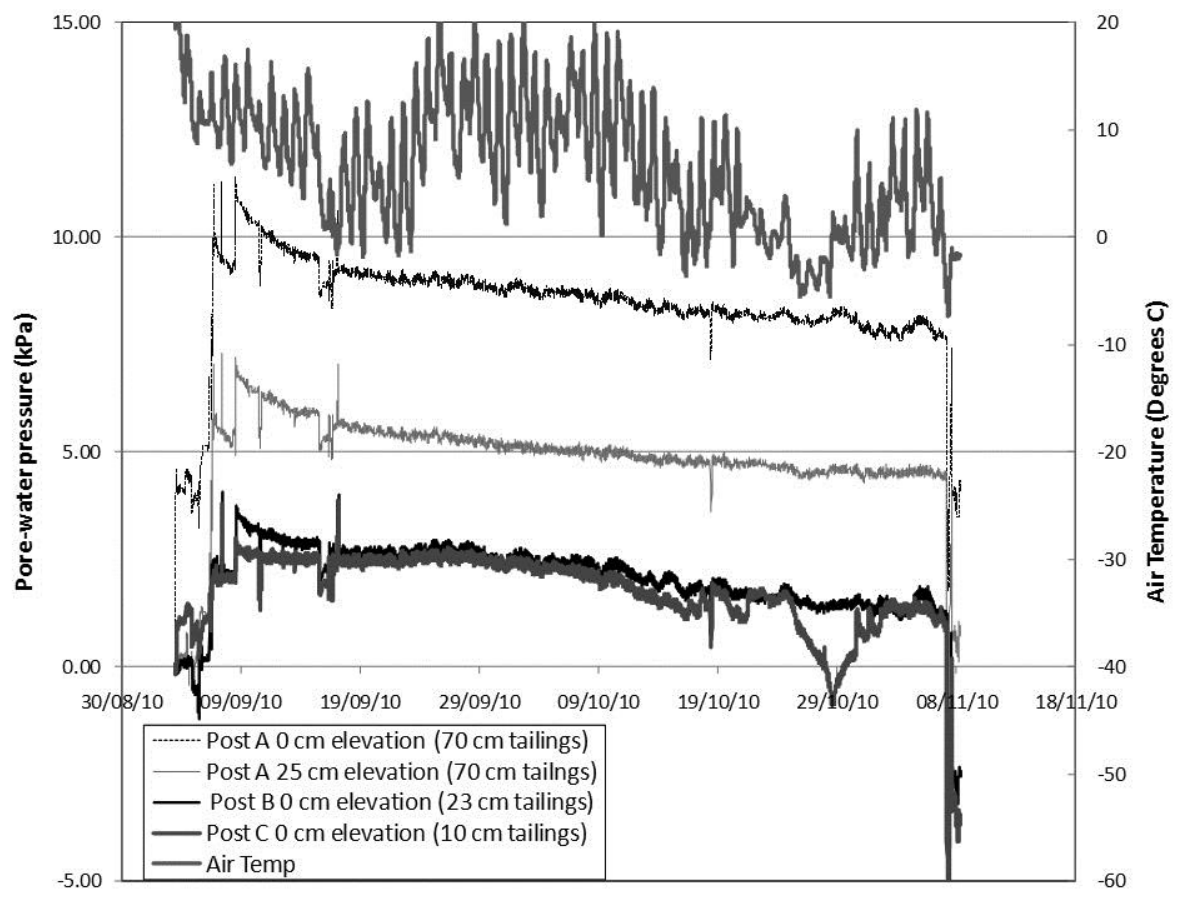

Figure 11 Pore-water pressures and air temperature in Cell 4

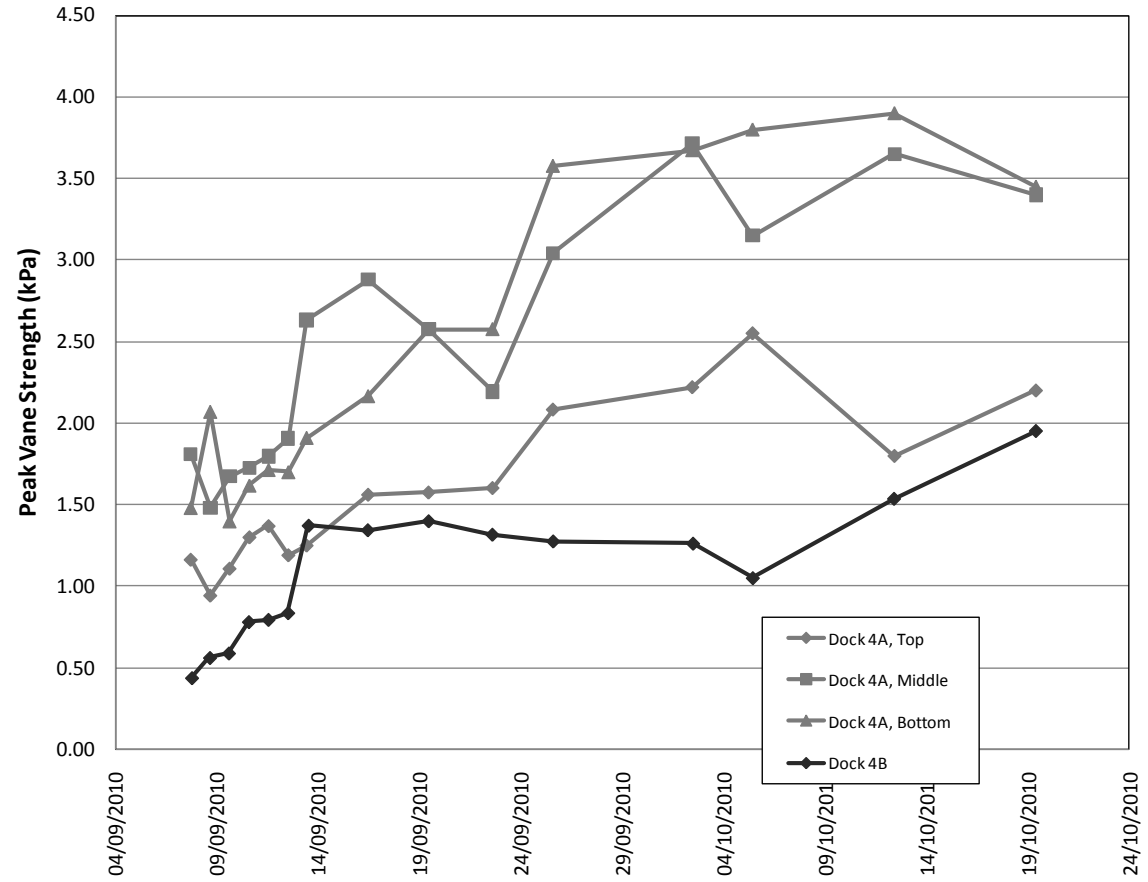

Figure 12 Peak vane strength in Cell 4 


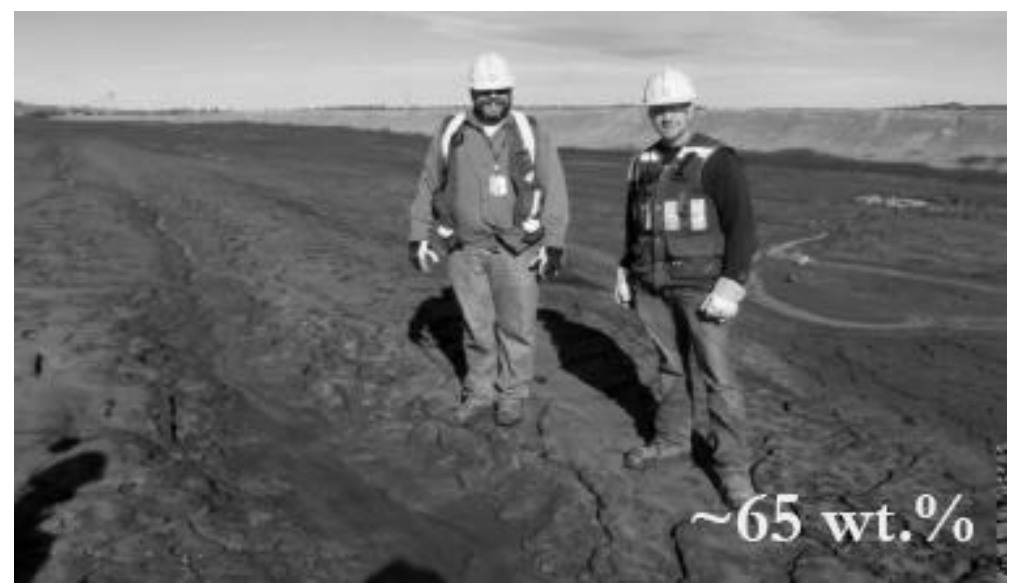

Figure 13 Best results for $30 \mathrm{~cm}$ depth - co-author $P$. House on the right

\section{Conclusions}

Some tentative conclusion can be hypothesised at this stage, pending further processing and analysis of the data:

1. Variability of the clay content in the MFT feed affected yield stress and therefore deposition geometry. This variability should be addressed when designing future deposition control mechanism.

2. Release water quality was generally good, and suitable for re-use in Shell's operations.

3. Consolidation appeared to be the primary mechanism for PWP dissipation and strength gain in these first trials. Density and vane strengths were higher at the bottom of the deposits. If true, the enhanced consolidation characteristics of the amended tailings would mean that the relative amount of work needed from atmospheric forcing to achieve necessary shear strengths would be less than expected. However, the role of consolidation after placement of additional layers, and the consequent change in drainage characteristics, still needs to be assessed.

4. Some evidence of atmospheric forcing, due to evaporation and/or freezing at the surface of the tailings, is observed in shallow piezometer data.

5. Best performance shows peak vane strengths of $5 \mathrm{kPa}$ achieved in a $30 \mathrm{~cm}$ thickness of tailings in one month. This is promising, due to the probability of enhanced consolidation for the tailings at depth as they are buried by successive lifts, and the probability of enhanced atmospheric forcing during the summer.

6. The influence of freezing-induced consolidation should be considered as a mechanism for strength gain, balanced against operational challenges for operating thin-lift deposition under freezing conditions.

\section{Acknowledgements}

Shell Canada would like to acknowledge the support of onsite personnel, Barr Engineering, and O'Kane Consultants.

\section{References}

Baskerville, R.C. and Gale, R.S. (1968) A Simple Automatic Instrument for Determining the Filterability of the Sewage Sludge, Water Pollution Control, Vol. 67, pp. 233-234.

Energy Resouces Conservation Board (ERCB) (2009) Directive 074: Tailings Performance Criteria and Requirements for Oil Sands Mining Schemes, February 2009.

Pashias, N., Boger, D.V., Summers, J. and Glenister, D.J. (1996) A fifty cent rheomoter for yield stress measurement, Journal of Rheology, Vol. 40(6), pp. 1179-1189. 